\title{
Comparison of Clinical, Laboratory and Radiological Findings in Iranian Smokers and non- Smokers Patients with COVID-19: A Case Control Study
}

\section{Mohamad Nikpouraghdam}

Baqiyatallah University of Medical Sciences

\section{Ali Bahramifar}

Baqiyatallah University of Medical Sciences

\section{Ali Ahmadi}

Baqiyatallah University of Medical Sciences

Dariuosh Ghasemi Vanegh Oliya

Baqiyatallah University of Medical Sciences

Abolfazl Jahangiri

Baqiyatallah University of Medical Sciences

\section{Masour Babaei}

Baqiyatallah University of Medical Sciences

Ali Mehdi Gholian

Baqiyatallah University of Medical Sciences

\section{Seyed Reza Hosseini Zijoud}

Shaheed Beheshti University of Medical Sciences

Hossein Aghamollaei ( $\nabla$ Aghamolaei22@gmail.com)

Baqiyatallah University of Medical Sciences https://orcid.org/0000-0001-8831-4108

\section{Research}

Keywords: COVID-19, SARS-CoV-2, Smoking, Tobacco, Cigarette, Iran

Posted Date: June 17th, 2020

DOl: https://doi.org/10.21203/rs.3.rs-34243/v1

License: (1) (i) This work is licensed under a Creative Commons Attribution 4.0 International License. Read Full License 


\section{Abstract}

Objective: The current study compared the clinical, laboratory and radiological findings between groups of smokers and non- smokers Iranian patients with COVID-19.

Methods: This was a case-control study done on 120 patients with COVID-19 that were admitted to Baqiyatallah hospital, Tehran, Iran during March to May 2020. Our patients were categorized into two groups: smokers (40 patients) and non-smokers (80 age and sex matched controls). Demographic and clinical characteristics, laboratory findings, imaging manifestations, and outcomes were compared between two age groups.

Results: Regarding the comorbidities, no significant difference was observed between the smoker and non-smoker patients. The distribution of COVID-19 symptoms was not significantly different between smokers and non-smokers, except for chest pain and weakness, which were significantly more common in smokers with COVID-19. A significantly lower white blood cell count and neutrophils in peripheral blood sample of smokers however, no difference was found concerning lymphocyte count. Moreover, the RDW of smokers was significantly lower. Regarding the findings on CT scan of COVID-19 patients, no significant difference was found between smoker and non-smoker COVID-19 patients. One $(2.5 \%)$ of deaths occurred in the smoker and $3(3.8 \%)$ occurred in the non- smoker groups.

Conclusion: Current findings showed that the clinical picture of smoker and non-smoker COVID-19 patients does not differ significantly.

\section{Introduction}

The new corona virus (SARS-CoV-2) has caused the ongoing pandemic that has infected more than four million and killed more than 280,000 people until May 10th, 2020 (1). Patients typically experience mild flu like symptoms, however a small proportion will progress to develop bilateral pneumonia and acute respiratory distress syndrome which may eventually result in death (2). Several studies have been conducted to identify the risk factors associated with severe disease and mortality. Comorbidities such as, cardiovascular diseases, COPD, diabetes, hypertension are thought to be associated with higher risk of severe disease $(3,4)$.

A potential comorbidity for COVID-19 patients is smoking, and approximately 1.3 billion people smoke globally making smoking a widespread habit that can have significant impact on the prognosis of COVID19 patients (5). Several studies have assessed the effect of smoking on the prognosis of COVID-19 however, the results of these studies are controversial $(4,6-12)$. Many studies suggest that smoking makes individuals more susceptible to COVID-19 and results in higher risk of severe disease and ICU admission $(11,13-15)$. Whereas, some studies implicate that not only smoking does not cause harm but also can have a protective role for patients with COVID-19, due to anti-inflammatory effects of nicotine (6, $16,17)$. Therefore, the exact influence of smoking on patients with COVID-19 still remains unknown. 
In this study we sought to compare the symptoms, laboratory findings and outcome of between smoker and non-smoker COVID-19 patients, and evaluate whether smoking changes the clinical course or outcome of COVID-19 patients.

\section{Materials And Methods}

This was a case-control study done on 120 patients with COVID-19 that were admitted to Baqiyatallah hospital, Tehran, Iran during March to May 2020. Our patients were categorized into two groups: Smokers (40 patients) and Non-smokers (80 age and sex matched controls).

Demographic and clinical data including age, sex, marital status, BMI, presenting signs and symptoms, outcome and days of hospital stay were extracted from patients' medical records. Smoking was defined as having a history of at least 0.5 packs per year.

Informed consent was obtained from all patients. This research was approved by the Ethics Committee of Baqiyatallah University of Medical Sciences.

\section{Statistical analysis}

Quantitative data are presented as mean \pm standard deviation. Normality of distribution was evaluated using Kolmogorov-Smirnoff test. In order to assess the relationship between different variables, chisquare or fisher extent tests were used for qualitative data and T-test and Mann-Whitney-U test were used for quantitative data, based on the distribution of data. Data analysis was done using SPSS version 23 and a p-value of less than 0.05 was considered statistically significant.

\section{Results}

Our study included 40 smoker COVID-19 patients and 80 age and sex matched non-smoker COVID-19 patients. The mean age of our patients was $51 \pm 12$ years and $74 \%$ of our patients were males. Mean BMI of our patients was $28.93 \pm 6.08 \mathrm{~kg} / \mathrm{m}^{2}$ and no significant difference was noted between the two groups in case of BMI.

Regarding the comorbidities, no significant difference was observed between the smoker and non-smoker patients. The most common comorbidities in our study population were hypertension, diabetes and COPD (Table 1). 
Table 1

Comparison of comorbidities between smoker and non-smoker COVID-19 patients

\begin{tabular}{|c|c|c|c|c|c|c|}
\hline & & \multicolumn{4}{|c|}{ Smoking } & \multirow[t]{3}{*}{ P-value } \\
\hline & & \multicolumn{2}{|l|}{ No } & \multicolumn{2}{|l|}{ Yes } & \\
\hline & & Count & Percent & Count & Percent & \\
\hline \multirow[t]{2}{*}{ Hypertension } & Yes & 19 & $23.8 \%$ & 8 & $20.0 \%$ & \multirow[t]{2}{*}{0.643} \\
\hline & No & 61 & $76.3 \%$ & 32 & $80.0 \%$ & \\
\hline \multirow[t]{2}{*}{ Diabetes } & Yes & 18 & $22.5 \%$ & 9 & $22.5 \%$ & \multirow[t]{2}{*}{1.000} \\
\hline & No & 62 & $77.5 \%$ & 31 & $77.5 \%$ & \\
\hline \multirow[t]{2}{*}{ Coronary Heart Disease } & Yes & 12 & $15.0 \%$ & 6 & $15.0 \%$ & \multirow[t]{2}{*}{1.000} \\
\hline & No & 68 & $85.0 \%$ & 34 & $85.0 \%$ & \\
\hline \multirow[t]{2}{*}{ Stroke } & Yes & 1 & $1.3 \%$ & 1 & $2.5 \%$ & \multirow[t]{2}{*}{0.614} \\
\hline & No & 79 & $98.8 \%$ & 39 & $97.5 \%$ & \\
\hline \multirow[t]{2}{*}{ COPD } & Yes & 14 & $17.5 \%$ & 5 & $12.5 \%$ & \multirow[t]{2}{*}{0.479} \\
\hline & No & 66 & $82.5 \%$ & 35 & $87.5 \%$ & \\
\hline \multirow{2}{*}{$\begin{array}{l}\text { Allergy } \\
\text { (missing = 1) }\end{array}$} & Yes & 9 & $11.3 \%$ & 7 & $17.9 \%$ & \multirow[t]{2}{*}{0.315} \\
\hline & No & 71 & $88.8 \%$ & 32 & $82.1 \%$ & \\
\hline \multirow[t]{2}{*}{ Kidney Disease } & Yes & 8 & $10.0 \%$ & 1 & $2.5 \%$ & \multirow[t]{2}{*}{0.141} \\
\hline & No & 72 & $90.0 \%$ & 39 & $97.5 \%$ & \\
\hline \multirow[t]{2}{*}{ Liver Disease } & Yes & 6 & $7.5 \%$ & 3 & $7.5 \%$ & \multirow[t]{2}{*}{1.000} \\
\hline & No & 74 & $92.5 \%$ & 37 & $92.5 \%$ & \\
\hline \multirow[t]{2}{*}{ Cancer } & Yes & 4 & $5.0 \%$ & 2 & $5.0 \%$ & \multirow[t]{2}{*}{1.000} \\
\hline & No & 76 & $95.0 \%$ & 38 & $95.0 \%$ & \\
\hline
\end{tabular}

As shown in Table 2, temperature, respiratory rate and oxygen saturation did not differ significantly between smokers and non-smokers. Moreover, as shown in Table 3, the distribution of COVID-19 symptoms was not significantly different between smokers and non-smokers, except for chest pain and weakness, which were significantly more common in smokers with COVID-19. 
Table 2

Comparison of Temperature, Respiratory rate and oxygen saturation between smoker and non-smoker COVID-19 patients

\begin{tabular}{|llllll|}
\hline & \multicolumn{2}{l}{ Smoking } & \multicolumn{3}{c|}{ P-Value } \\
\cline { 2 - 5 } & No & \multicolumn{2}{c}{ Yes } & \\
\cline { 2 - 5 } & Mean \pm Std & Median & Mean \pm Std & Median & \\
\hline Temperature $\left({ }^{\circ} \mathrm{C}\right)$ & $37.8 \pm 1.1$ & 37.8 & $37.5 \pm 1.3$ & 37.6 & 0.708 \\
\hline Respiratory Rate (per min) & $19 \pm 3$ & 18 & $20 \pm 4$ & 18 & 0.970 \\
\hline Oxygen Saturation (\%) & $89.04 \pm 7.68$ & 91.00 & $89.81 \pm 5.8$ & 90.50 & 0.888 \\
\hline
\end{tabular}


Table 3

Comparison of symptoms between smoker and non-smoker COVID-19 patients

\begin{tabular}{|c|c|c|c|c|c|c|}
\hline & & \multicolumn{4}{|c|}{ Smoking } & \multirow[t]{3}{*}{ P-value } \\
\hline & & \multicolumn{2}{|l|}{ No } & \multicolumn{2}{|l|}{ Yes } & \\
\hline & & Count & Percent & Count & Percent & \\
\hline \multirow[t]{2}{*}{ Cough (missing = 3 ) } & Yes & 51 & $65.4 \%$ & 26 & $66.7 \%$ & \multirow[t]{2}{*}{0.890} \\
\hline & No & 27 & $34.6 \%$ & 13 & $33.3 \%$ & \\
\hline \multirow[t]{2}{*}{ Dyspnea (missing = 2) } & Yes & 46 & $57.5 \%$ & 24 & $63.2 \%$ & \multirow[t]{2}{*}{0.559} \\
\hline & No & 34 & $42.5 \%$ & 14 & $36.8 \%$ & \\
\hline \multirow[t]{2}{*}{ Chest Pain (missing $=3$ ) } & Yes & 14 & $17.7 \%$ & 13 & $34.2 \%$ & \multirow[t]{2}{*}{0.047} \\
\hline & No & 65 & $82.3 \%$ & 25 & $65.8 \%$ & \\
\hline \multirow[t]{2}{*}{ Headache $($ missing $=3$ ) } & Yes & 25 & $32.1 \%$ & 19 & $48.7 \%$ & \multirow[t]{2}{*}{0.079} \\
\hline & No & 53 & $67.9 \%$ & 20 & $51.3 \%$ & \\
\hline \multirow[t]{2}{*}{ Dizziness (missing = 37) } & Yes & 8 & $13.6 \%$ & 3 & $12.5 \%$ & \multirow[t]{2}{*}{0.897} \\
\hline & No & 51 & $86.4 \%$ & 21 & $87.5 \%$ & \\
\hline \multirow[t]{2}{*}{ Weakness (missing = 3) } & Yes & 44 & $55.7 \%$ & 29 & $76.3 \%$ & \multirow[t]{2}{*}{0.031} \\
\hline & No & 35 & $44.3 \%$ & 9 & $23.7 \%$ & \\
\hline \multirow[t]{2}{*}{ Myalgia (missing = 1) } & Yes & 42 & $52.5 \%$ & 27 & $69.2 \%$ & \multirow[t]{2}{*}{0.083} \\
\hline & No & 38 & $47.5 \%$ & 12 & $30.8 \%$ & \\
\hline \multirow[t]{2}{*}{ Chills (missing = 2) } & Yes & 41 & $51.9 \%$ & 24 & $61.5 \%$ & \multirow[t]{2}{*}{0.322} \\
\hline & No & 38 & $48.1 \%$ & 15 & $38.5 \%$ & \\
\hline \multirow[t]{2}{*}{ Rhinorrhea (missing = 2) } & Yes & 7 & $8.9 \%$ & 5 & $12.8 \%$ & \multirow[t]{2}{*}{0.503} \\
\hline & No & 72 & $91.1 \%$ & 34 & $87.2 \%$ & \\
\hline \multirow[t]{2}{*}{ Sore Throat (missing = 2) } & Yes & 9 & $11.4 \%$ & 7 & $17.9 \%$ & \multirow[t]{2}{*}{0.328} \\
\hline & No & 70 & $88.6 \%$ & 32 & $82.1 \%$ & \\
\hline \multirow[t]{2}{*}{ Diarrhea (missing = 2) } & Yes & 10 & $12.7 \%$ & 10 & $25.6 \%$ & \multirow[t]{2}{*}{0.077} \\
\hline & No & 69 & $87.3 \%$ & 29 & $74.4 \%$ & \\
\hline \multirow[t]{2}{*}{ Vomiting (missing = 2) } & Yes & 26 & $32.9 \%$ & 14 & $35.9 \%$ & \multirow[t]{2}{*}{0.747} \\
\hline & No & 53 & $67.1 \%$ & 25 & $64.1 \%$ & \\
\hline Sputum production (missing $=2$ ) & Yes & 13 & $16.5 \%$ & 8 & $20.5 \%$ & 0.588 \\
\hline
\end{tabular}




\begin{tabular}{|c|c|c|c|c|c|c|}
\hline & No & 66 & $83.5 \%$ & 31 & $79.5 \%$ & \\
\hline \multirow[t]{2}{*}{ Loss of Smelling sense (missing $=36$ ) } & Yes & 14 & $23.3 \%$ & 9 & $37.5 \%$ & \multirow[t]{2}{*}{0.188} \\
\hline & No & 46 & $76.7 \%$ & 15 & $62.5 \%$ & \\
\hline \multirow[t]{2}{*}{ Loss of Taste sense (missing = 37) } & Yes & 14 & $23.7 \%$ & 8 & $33.3 \%$ & \multirow[t]{2}{*}{0.369} \\
\hline & No & 45 & $76.3 \%$ & 16 & $66.7 \%$ & \\
\hline \multirow[t]{2}{*}{ Earache (missing = 37) } & Yes & 6 & $10.2 \%$ & 3 & $12.5 \%$ & \multirow[t]{2}{*}{0.757} \\
\hline & No & 53 & $89.8 \%$ & 21 & $87.5 \%$ & \\
\hline
\end{tabular}

We also compared the laboratory findings between smokers and non-smokers. Our results showed a significantly lower white blood cell count and neutrophils in peripheral blood sample of smokers however, no difference was found concerning lymphocyte count. Moreover, the RDW of smokers was significantly lower. Regarding other tests including CRP, ESR and creatinine no statistically significant difference was found between the two groups (Table 4). 
Table 4

Comparison of laboratory data between smoker and non-smoker COVID-19 patients Smoking

No Yes

Pvalue

Mean $\begin{gathered}\text { Standard Median Mean } \\ \text { Deviation }\end{gathered}$ Standard Median

\begin{tabular}{|c|c|c|c|c|c|c|c|}
\hline WBC (cells $/ \mathrm{mm}^{3}$ ) & 8.28 & 3.64 & 7.70 & 5.77 & 1.83 & 5.50 & 0.001 \\
\hline $\mathrm{RBC}\left(\right.$ cells $/ \mathrm{mm}^{3}$ ) & 5.01 & 0.71 & 4.99 & 4.79 & 0.50 & 4.77 & 0.22 \\
\hline Hemoglobin $(\mathrm{g} / \mathrm{dl})$ & 14.41 & 1.91 & 14.55 & 14.49 & 1.55 & 14.55 & 0.846 \\
\hline Hematocrit (\%) & 42.19 & 4.75 & 42.40 & 41.92 & 3.88 & 42.45 & 0.846 \\
\hline MCV (fL) & 84.76 & 7.77 & 86.10 & 87.70 & 3.65 & 86.74 & 0.561 \\
\hline $\mathrm{MCH}(\mathrm{pg})$ & 29.76 & 7.46 & 29.88 & 29.55 & 4.39 & 30.15 & 0.846 \\
\hline $\mathrm{MCHC}(\mathrm{g} / \mathrm{dl})$ & 34.05 & 1.63 & 34.39 & 34.55 & 1.22 & 34.55 & 0.478 \\
\hline $\begin{array}{l}\text { Platelets } \\
\text { (cells } / \mathrm{mm}^{3} \text { ) }\end{array}$ & 211 & 83 & 190 & 170 & 63 & 157 & 0.081 \\
\hline RDW (\%) & 13.64 & 1.64 & 13.10 & 12.81 & 0.79 & 12.70 & 0.023 \\
\hline $\begin{array}{l}\text { Neutrophil count } \\
\text { (cells } / \mathrm{mm}^{3} \text { ) }\end{array}$ & 6378 & 3468 & 5500 & 4033 & 1816 & 3667 & 0.001 \\
\hline $\begin{array}{l}\text { Lymphocyte count } \\
\left(\text { cells } / \mathrm{mm}^{3}\right)\end{array}$ & 1301 & 696 & 1113 & 1352 & 1186 & 1101 & 0.805 \\
\hline MPV (fL) & 9.99 & 1.18 & 9.90 & 10.03 & 0.90 & 10.00 & 0.561 \\
\hline $\mathrm{ESR}(\mathrm{mm} / \mathrm{hr})$ & 48.65 & 27.02 & 47.00 & 40.11 & 25.27 & 36.50 & 0.316 \\
\hline $\begin{array}{l}\text { Blood Sugar } \\
(\mathrm{mg} / \mathrm{dl})\end{array}$ & 157.08 & 72.17 & 127.00 & 149.36 & 85.56 & 115.00 & 0.201 \\
\hline BUN (mg/dl) & 15 & 6 & 14 & 14 & 6 & 12 & 0.381 \\
\hline Creatinine $(\mathrm{mg} / \mathrm{dl})$ & 1.07 & 0.28 & 1.00 & 1.29 & 1.19 & 1.00 & 0.840 \\
\hline $\mathrm{SGOT}(\mathrm{mg} / \mathrm{dl})$ & 41.83 & 21.58 & 36.00 & 49.41 & 58.19 & 36.50 & 0.947 \\
\hline SGPT (mg/dl) & 33.82 & 24.75 & 28.50 & 40.19 & 37.37 & 28.50 & 0.827 \\
\hline
\end{tabular}

WBC: White Blood Cells, RBC: Red Blood Cells, MCV: Mean Corpuscular Volume, MCH: Mean Corpuscular Hemoglobin, MCHC: mean corpuscular hemoglobin concentration, RDW: red cell distribution width, MPV: Mean Platelets Volume, ESR: erythrocyte sedimentation rate, BUN: Blood Urea Nitrogen, SGOT: Serum glutamic oxaloacetic transaminase, SGPT: Serum glutamic pyruvic transaminase, ALP: Alkaline phosphatase, CPK: Creatine phosphokinase, LDH: Lactate Dehydrogenase, CRP: C-reactive protein 


\begin{tabular}{|c|c|c|c|c|c|c|c|}
\hline & \multicolumn{6}{|c|}{ Smoking } & \multirow{3}{*}{$\begin{array}{l}\mathrm{P} \text { - } \\
\text { value }\end{array}$} \\
\hline & \multicolumn{3}{|l|}{ No } & \multicolumn{3}{|l|}{ Yes } & \\
\hline & Mean & $\begin{array}{l}\text { Standard } \\
\text { Deviation }\end{array}$ & Median & Mean & $\begin{array}{l}\text { Standard } \\
\text { Deviation }\end{array}$ & Median & \\
\hline $\operatorname{ALP}(\mathrm{mg} / \mathrm{dl})$ & 179.34 & 64.09 & 170.00 & 182.63 & 56.16 & 177.00 & 0.868 \\
\hline $\mathrm{CPK}(\mathrm{mg} / \mathrm{dl})$ & 170.80 & 125.58 & 122.50 & 226.26 & 283.22 & 141.00 & 0.561 \\
\hline $\mathrm{LDH}(\mathrm{mg} / \mathrm{dl})$ & 703.72 & 287.94 & 642.50 & 763.00 & 526.35 & 618.00 & 0.703 \\
\hline Sodium (mEq/L) & 135 & 4 & 135 & 135 & 3 & 136 & 0.308 \\
\hline Potassium (mEq/L) & 4.31 & 0.55 & 4.20 & 4.10 & 0.41 & 4.05 & 0.213 \\
\hline $\mathrm{CRP}(\mathrm{mg} / \mathrm{L})$ & 57.82 & 45.43 & 45.30 & 45.19 & 31.70 & 40.50 & 0.696 \\
\hline \multicolumn{8}{|c|}{$\begin{array}{l}\text { WBC: White Blood Cells, RBC: Red Blood Cells, MCV: Mean Corpuscular Volume, MCH: Mean } \\
\text { Corpuscular Hemoglobin, MCHC: mean corpuscular hemoglobin concentration, RDW: red cell } \\
\text { distribution width, MPV: Mean Platelets Volume, ESR: erythrocyte sedimentation rate, BUN: Blood Urea } \\
\text { Nitrogen, SGOT: Serum glutamic oxaloacetic transaminase, SGPT: Serum glutamic pyruvic } \\
\text { transaminase, ALP: Alkaline phosphatase, CPK: Creatine phosphokinase, LDH: Lactate } \\
\text { Dehydrogenase, CRP: C-reactive protein }\end{array}$} \\
\hline
\end{tabular}

Regarding the findings on CT scan of COVID-19 patients, no significant difference was found between smoker and non-smoker COVID-19 patients (Table 5). The most common findings of imaging was bilateral patchy ground glass opacities suggestive of viral or atypical pneumonia. 
Table 5

Comparison of CT scan findings between smoker and non-smoker COVID-19 patients

\begin{tabular}{|c|c|c|c|c|c|c|}
\hline & & \multicolumn{4}{|c|}{ Smoking } & \multirow[t]{3}{*}{ P-value } \\
\hline & & \multicolumn{2}{|l|}{ No } & \multicolumn{2}{|l|}{ Yes } & \\
\hline & & Count & Percent & Count & Percent & \\
\hline \multirow{3}{*}{$\begin{array}{l}\text { Affected Lung } \\
(\mathrm{N}=75)\end{array}$} & Right & 0 & $0.0 \%$ & 0 & $0.0 \%$ & \multirow[t]{3}{*}{0.242} \\
\hline & Left & 2 & $4.4 \%$ & 0 & $0.0 \%$ & \\
\hline & Bilateral & 43 & $95.6 \%$ & 30 & $100.0 \%$ & \\
\hline \multirow{2}{*}{$\begin{array}{l}\text { Patchy Ground Glass opacity } \\
(\mathrm{N}=75)\end{array}$} & No & 2 & $4.4 \%$ & 2 & $6.7 \%$ & \multirow[t]{2}{*}{0.675} \\
\hline & Yes & 43 & $95.6 \%$ & 28 & $93.3 \%$ & \\
\hline \multirow{2}{*}{$\begin{array}{l}\text { Crazy Paving } \\
(\mathrm{N}=75)\end{array}$} & No & 41 & $91.1 \%$ & 26 & $86.7 \%$ & \multirow[t]{2}{*}{0.541} \\
\hline & Yes & 4 & $8.9 \%$ & 4 & $13.3 \%$ & \\
\hline \multirow{2}{*}{$\begin{array}{l}\text { Reverse Halo } \\
(\mathrm{N}=75)\end{array}$} & No & 44 & $97.8 \%$ & 26 & $86.7 \%$ & \multirow[t]{2}{*}{0.059} \\
\hline & Yes & 1 & $2.2 \%$ & 4 & $13.3 \%$ & \\
\hline \multirow{2}{*}{$\begin{array}{l}\text { Consolidation } \\
(\mathrm{N}=75)\end{array}$} & No & 40 & $88.9 \%$ & 26 & $86.7 \%$ & \multirow[t]{2}{*}{0.772} \\
\hline & Yes & 5 & $11.1 \%$ & 4 & $13.3 \%$ & \\
\hline \multirow{2}{*}{$\begin{array}{l}\text { Linear Opacity } \\
(\mathrm{N}=75)\end{array}$} & No & 43 & $95.6 \%$ & 29 & $96.7 \%$ & \multirow[t]{2}{*}{0.810} \\
\hline & Yes & 2 & $4.4 \%$ & 1 & $3.3 \%$ & \\
\hline \multirow{2}{*}{$\begin{array}{l}\text { Enlarged Lymph Node } \\
(\mathrm{N}=75)\end{array}$} & No & 43 & $95.6 \%$ & 28 & $93.3 \%$ & \multirow[t]{2}{*}{0.675} \\
\hline & Yes & 2 & $4.4 \%$ & 2 & $6.7 \%$ & \\
\hline \multirow{2}{*}{$\begin{array}{l}\text { Pleural Effusion } \\
(\mathrm{N}=75)\end{array}$} & No & 43 & $95.6 \%$ & 27 & $90.0 \%$ & \multirow[t]{2}{*}{0.345} \\
\hline & Yes & 2 & $4.4 \%$ & 3 & $10.0 \%$ & \\
\hline \multirow{2}{*}{$\begin{array}{l}\text { Air cyst } \\
(\mathrm{N}=75)\end{array}$} & No & 44 & $97.8 \%$ & 29 & $96.7 \%$ & \multirow[t]{2}{*}{0.770} \\
\hline & Yes & 1 & $2.2 \%$ & 1 & $3.3 \%$ & \\
\hline \multirow{2}{*}{$\begin{array}{l}\text { Atelectasis } \\
(\mathrm{N}=75)\end{array}$} & No & 43 & $95.6 \%$ & 30 & $100.0 \%$ & \multirow[t]{2}{*}{0.242} \\
\hline & Yes & 2 & $4.4 \%$ & 0 & $0.0 \%$ & \\
\hline \multirow{2}{*}{$\begin{array}{l}\text { Thickened Interlobular Septa } \\
(\mathrm{N}=75)\end{array}$} & No & 44 & $97.8 \%$ & 28 & $93.3 \%$ & \multirow[t]{2}{*}{0.336} \\
\hline & Yes & 1 & $2.2 \%$ & 2 & $6.7 \%$ & \\
\hline
\end{tabular}

Finally we compared the days of hospital stay and rate of discharge, readmission and death between smokers and non-smokers. As shown in Fig. 1 and Table 6, none of these aforementioned factors were 
statistically different among the two groups.

Table 6

Comparison of Discharge, Readmission and Death rate between smoker and non-smoker COVID-19 patients

\begin{tabular}{|c|c|c|c|c|c|c|}
\hline & & \multicolumn{4}{|c|}{ Smoking } & \multirow[t]{3}{*}{ P-value } \\
\hline & & \multicolumn{2}{|l|}{ No } & \multicolumn{2}{|l|}{ Yes } & \\
\hline & & Count & Percent & Count & Percent & \\
\hline \multirow[t]{2}{*}{ Readmission } & No & 49 & $86.0 \%$ & 27 & $87.1 \%$ & \multirow[t]{2}{*}{1.000} \\
\hline & Yes & 8 & $14.0 \%$ & 4 & $12.9 \%$ & \\
\hline \multirow[t]{2}{*}{ Death } & No & 77 & $96.2 \%$ & 39 & $97.5 \%$ & \multirow[t]{2}{*}{1.000} \\
\hline & Yes & 3 & $3.8 \%$ & 1 & $2.5 \%$ & \\
\hline
\end{tabular}

\section{Discussion}

Here we evaluated the clinical signs and symptoms, laboratory data, imaging findings and outcomes of COVID-19 patients, and compared the smokers with non-smoker patients. Because it has been shown that age and gender significantly affect the clinical picture and outcome of COVID-19 patients $(13,18)$, we used an age and sex matched control group to eliminate the effect of age and sex in the comparison. Moreover, the prevalence of different comorbidities were not significantly different between smokers and non-smokers. Therefore, any differences in clinical picture or outcome of COVID-19 in our study, cannot be attributed to differences in comorbidities between smokers and non-smokers. Regarding the signs and symptoms of COVID-19, our data demonstrated that smokers are more likely to exhibit chest pain and weakness compared to non-smoker patients. In addition, the number of white blood cells and neutrophils were significantly lower in smokers. However, concerning the clinical outcome of COVID-19 patients, such as days of hospital stay, rate of discharge, readmission and death, our data indicated that no significant difference exists between smokers and non-smokers.

Since the start of SARS-CoV-2 epidemic, several studies have been carried out to identify the role of smoking in clinical picture and disease outcome, however the obtained results are contradictory. Apart from various editorials that have emphasized on the detrimental effects of smoking on COVID-19 patients and severity of the disease $(19,20)$, many original articles and meta-analyses also indicated that smoker patients have a poorer prognosis compared to non-smokers $(11,13-15,21)$. Liu et al, evaluated 78 patients with COVID-19 and reported that patients with progressive disease were more likely to be smokers compared to patients who had improvement/stabilization (13). Moreover, they showed that patients with a history of smoking are roughly 14 times more likely to develop progressive disease. Two systematic reviews also demonstrated that smoking is a risk factor for more severe disease in COVID-19 patients $(14,15)$. The main principle proposed for this increase in disease severity among smokers, is that smoking results in augmented expression of ACE-2 receptors in lung tissues, and as shown 
previously, SARS-CoV-2 exploits ACE-2 receptors to enter the pneumocytes and proliferate in them (20, 21). Thus, smokers may be more susceptible to corona virus and experience more severe disease. Another plausible explanation is that smoking causes several diseases such as COPD and cardiovascular disease, which puts smokers at a higher risk compared to non-smokers (19). Accordingly, we excluded smoker patients with other comorbidities from our study and demonstrated that smokers do not differ from non-smokers in case of disease outcomes.

On the other hand, several authors suggested that smoking may not be as harmful as thought. A systematic review conducted by Rubio et al. demonstrated that the proportion of smokers among COVID19 patients is significantly lower than the percentage of smokers among general population in three different countries including China, Italy and the USA. Thus, they postulated that smokers are significantly less likely to develop severe disease and be hospitalized (16). The proposed mechanism is that nicotine can alleviate the ongoing inflammatory responses and cytokine storm in COVID-19 patients through the cholinergic anti-inflammatory pathway. Forsalinos et al. also showed the same pattern of smoking in COVID-19 patients and general population in China. They hypothesized that COVID-19 symptoms result from a dysfunction of nicotinic cholinergic system and nicotine may be beneficial for patients as it can inhibit pro-inflammatory cytokines, while, not affecting the anti-inflammatory cytokines, through the a7 nicotinic acetyl choline receptors (a7-nAChRs). Ultimately, they suggested evaluating nicotine as an adjunct therapy for COVID-19 patients in clinical trials $(6,17)$.

Our results are in line with two systematic reviews that showed smoking does not significantly affect the outcome of COVID-19 patients $(18,22)$. This can be explained by the complex interplay of smoking and coronavirus. Although smoking may enhance the expression of ACE-2 receptors and expose patients to harmful chemical and make them susceptible to various diseases, its nicotine content may inhibit inflammatory responses thus neutralizing the detrimental effects of smoking for COVID-19 patients. Nevertheless we found some differences between smoker and non-smoker COVID-19 patients, including higher prevalence of weakness and chest pain and lower number of white blood cells and neutrophils in smokers. However, these differences are not clinically significant and does not change the clinical course or treatment options.

Our study had several limitations, for instance we did not evaluate other clinical outcomes such as the need for ICU admission or mechanical ventilation. Moreover, some patients' data were missing especially CT scan findings of 45 patients were not available. However, having an age and sex matched control group with similar comorbidities compared to smoker COVID-19 patients is the strength of our study.

\section{Conclusion}

Our results showed that the clinical picture of smoker and non-smoker COVID-19 patients does not differ significantly, and in contrast to the common thought that smoking causes more severe disease in COVID19 patients, our data showed no significant difference among smokers and non-smokers. Therefore we 
suggest that, even though smoking cannot be advertised as a treatment for COVID-19 due to its various detrimental effects, evaluating nicotine as an adjunct therapy may be a promising option.

\section{Abbreviations}

Coronavirus disease 2019

COVID-19;

Severe acute respiratory syndrome coronavirus 2

SARS-CoV-2;

World Health Organization

WHO

Computed tomography

CT;

Acute respiratory distress syndrome

ARDS;

Reverse transcription-polymerase chain reaction

RT-PCR;

Lactate dehydrogenase

LDH;

C-reactive protein

CRP;

Intensive care unit

ICU;

\section{Declarations}

\section{Acknowledgment}

Thanks to guidance and advice from the "Clinical Research Development Unit of Baqiyatallah Hospital". The authors gratefully acknowledge and in memory of all medical staff, as well as thousands of unsung heroes participate in the frontline in the fight against the epidemic of SARS-CoV-2.

\section{Authors' contributions}

$M N, A B$ and $H A$ were responsible for study concept and design. $A A, D G V O, A J, M B$, and $A M G$ led data collection. $\mathrm{HA}, \mathrm{SRHZ}$, and $A B$ were responsible for the analysis and interpretation of data. $H A, A A$ and DGVO wrote the first draft. $A B, A A, D G V O, A J, M B$, and $A M G$ contributed to the writing of the second and third draft. SRHZ provided comments on initial drafts and coordinated the final draft. All authors read and approved the final manuscript. All authors take responsibility for the integrity of the data and the accuracy of the data analysis.

\section{Funding}


Thanks to financial support, guidance and advice from the "Clinical Research Development Unit of Baqiyatallah Hospital".

\section{Role of the funding source}

The funder of the study had no role in study design, data collection, data analysis, data interpretation, or writing of the report.

\section{Availability of data and materials}

The data used in this study are available from the corresponding author on request.

\section{Ethics approval and consent to participate}

The study was conducted in accordance with the Declaration of Helsinki and Institutional Review Board approval has been obtained.

\section{Consent for publication}

By submitting this document, the authors declare their consent for the final accepted version of the manuscript to be considered for publication.

\section{Competing interests}

The authors declare that they have no competing interests.

\section{References}

1. Worldometer [Internet]. [cited May 10th 2020]. Available from: https://www.worldometers.info/coronavirus/.

2. Wu Z, McGoogan JMJJ. Characteristics of and important lessons from the coronavirus disease 2019 (COVID-19) outbreak in China: summary of a report of 72314 cases from the Chinese. Center for Disease Control Prevention. 2020;323(13):1239-42.

3. Yang J, Zheng Y, Gou X, Pu K, Chen Z, Guo Q, et al. Prevalence of comorbidities in the novel Wuhan coronavirus (COVID-19) infection: a systematic review and meta-analysis. 2020.

4. Jordan RE, Adab P, Cheng K. Covid-19: risk factors for severe disease and death. British Medical Journal Publishing Group; 2020.

5. Mackay J. The global epidemiology of tobacco and related chronic diseases. Public Health. 2012;126(3):199-201.

6. Farsalinos K, Barbouni A, Niaura RJQ. Smoking, vaping and hospitalization for COVID-19. 2020.

7. Lewis TJSA. Smoking or Vaping May Increase the Risk of Severe Coronavirus Infection. 2020;17. 
8. Lippi G, Henry BMJEjoim. Active smoking is not associated with severity of coronavirus disease 2019 (COVID-19). 2020.

9. Rossato M, Russo L, Mazzocut S, Di Vincenzo A, Fioretto P, Vettor RJERJ. Current smoking is not associated with COVID-19. 2020.

10. Vardavas Cl, Nikitara, KJTid. COVID-19 and smoking: A systematic review of the evidence. 2020;18.

11. Wang J, Luo Q, Chen R, Chen T, Li J. Susceptibility Analysis of COVID-19 in Smokers Based on ACE2. 2020.

12. Zhao Q, Meng M, Kumar R, Wu Y, Huang J, Lian N, et al. The impact of COPD and smoking history on the severity of Covid-19: A systemic review and meta-analysis. 2020.

13. Liu W, Tao Z-W, Wang L, Yuan M-L, Liu K, Zhou L, et al. Analysis of factors associated with disease outcomes in hospitalized patients with 2019 novel coronavirus disease. Chinese medical journal. 2020.

14. Rahman A, Sathi NJ. Risk Factors of the Severity of COVID-19: A Meta-Analysis. medRxiv. 2020.

15. Vardavas Cl, Nikitara K. COVID-19 and smoking: A systematic review of the evidence. Tobacco induced diseases. 2020;18.

16. Gonzalez-Rubio J, Navarro-Lopez C, Lopez-Najera E, Lopez-Najera A, Jiménez-Díaz L, Navarro-López JD, et al. What is Happening with Smokers and COVID-19? A Systematic Review and a MetaAnalysis. 2020.

17. Niaura R, Poulas K, Kouretas D, Barbouni A, Tsatsakis A, Farsalinos K, et al. Nicotine and SARS-CoV2: COVID-19 may be a disease of the nicotinic cholonergic system. 2020.

18. Baradaran A, Ebrahimzadeh MH, Baradaran A, Kachooei AR. Prevalence of Comorbidities in COVID19 Patients: A Systematic Review and Meta-Analysis. The Archives of Bone.

19. Joint Surgery. 2020;8(Covid-19 Special Issue):0-.

20. Simons D, Brown J, Shahab L, Perski O. Smoking and COVID-19: Rapid evidence review for the Royal College of Physicians, London (UK). J Qeios. 2020.

21. Brake SJ, Barnsley K, Lu W, McAlinden KD, Eapen MS, Sohal SS. Smoking upregulates angiotensinconverting enzyme-2 receptor: a potential adhesion site for novel coronavirus SARS-CoV-2 (Covid19). Multidisciplinary Digital Publishing Institute; 2020.

22. Leung JM, Yang CX, Tam A, Shaipanich T, Hackett T-L, Singhera GK, et al. ACE-2 Expression in the Small Airway Epithelia of Smokers and COPD Patients: Implications for COVID-19. European Respiratory Journal. 2020.

23. Xu L, Chen G. Risk factors for severe corona virus disease 2019 (COVID-19) patients: a systematic review and meta analysis. medRxiv. 2020.

\section{Figures}




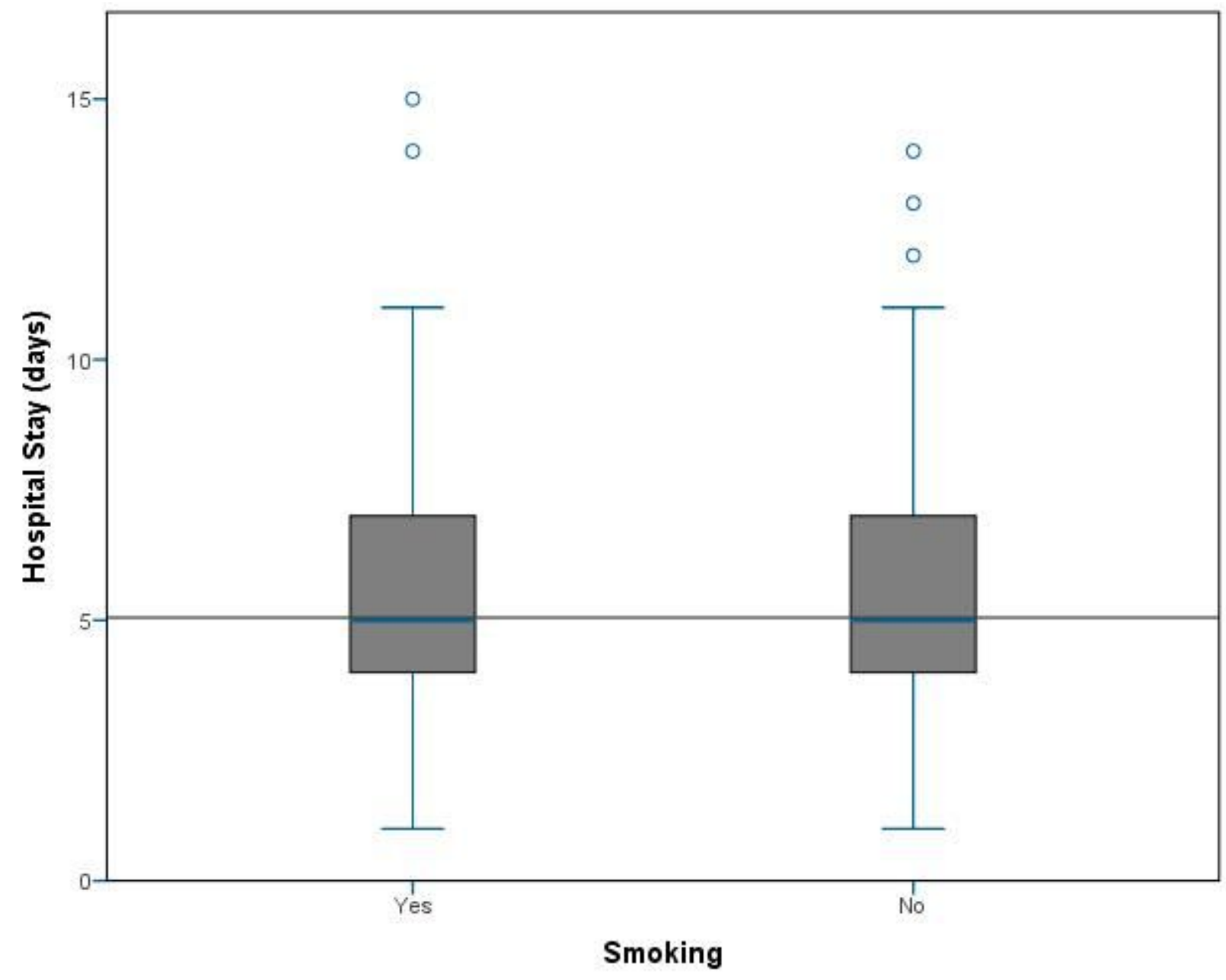

Figure 1

Comparing the days of hospital stay between smokers and non-smokers with COVID-19 